\title{
Sexual Violence and Substantive Equality: Can Restorative Justice Deliver?
}

\author{
Shirley Jülich ${ }^{1}$ - Natalie Thorburn ${ }^{2}$
}

Published online: 25 May 2017

(C) Springer International Publishing 2017

\begin{abstract}
The effects of sexual crimes upon victims and the wider community are pervasive and far-reaching, yet conventional attempts to address offending and seek justice for victims have not succeeded; rather, they have left victims without a sense of justice and often magnified the adverse impacts of the initial victimization. The applicability and appropriateness of restorative justice to such gendered categories of crime has been long debated, but emerging evidence suggests that it may offer victims greater satisfaction by way of recognition of the need for substantive over procedural equality, and consequent privileging of victims' needs and experiences. This focus on substantive equality and its implications for justice also aligns with international covenants, which recognize the inadequacy of formal equality and traditional approaches to justice when addressing crimes where perpetration is dependent on the manifestation of power and control. The article therefore sets out the case for restorative justice in accordance with these imperatives for substantive equality, and discusses the challenges inherent in providing safe restorative practices.
\end{abstract}

Keywords Sexual violence $\cdot$ Substantive equality $\cdot$ Human rights $\cdot$ Restorative justice

Natalie Thorburn

N.Thorburn@auckland.ac.nz

Shirley Jülich

S.J.Julich@Massey.ac.nz

1 Massey University, Palmerston North, New Zealand

2 University of Auckland, Auckland, New Zealand

\section{Introduction}

The consequences of sexual violence - emotional, psychological and economic - and their impacts on health, self-esteem and well-being have far-reaching implications for victims, their families and their communities. Not surprisingly, the effectiveness of interventions and, in particular, criminal justice interventions, is debated heatedly in our communities. Complicating this debate are the very different understandings and expectations that various stakeholders have of a justice system that reflects the patriarchal structures of our society. While justice means different things to different people, there is an acknowledgement that conventional criminal justice systems typically do not provide victims of sexual violence with an experience of justice. For too many women (and men) in our communities, sexual violence is a reality. (Triggs et al. 2009) Many are reluctant to report victimization to the police; consequently, the majority of perpetrators are not held to account. This article first sets out the nature of sexual violence, victims' barriers to experiencing justice and the social work imperative for responsive practice, before discussing the historically situated notion of 'equality' and approaches to equality in addressing the harm caused by sexual violence. It then discusses the 'fit' of restorative justice as an instrument for advancing equality, and concludes by considering the specialist skills and resourcing necessary to ensure the appropriateness of restorative justice for sexual crimes.

There is no shortage of literature attesting to the incidence and prevalence of sexual violence (Jordan 2004). Studies indicate that as many as $33 \%$ of women will be subjected to sexual violence at some point in their lives (Walby and Myhill 2001). While men too are subject to sexual violence, this paper focuses specifically on recourse available to women and girls subjected to sexual violence in recognition of the highly gendered nature of the crime. Sexual violence against 
women, particularly that which occurs as a result of an inherent gendered power differential, has been long recognized as a violation of women's human rights and is stated as such in General Recommendation 19 of the Convention for the Elimination of All Forms of Discrimination Against Women (CEDAW) (UN Women 2009). Researchers consistently find that women who have been sexually abused tend to remain silent (Mayhew and Reilly 2007; Weiss 2011). Their reasons for doing so are varied and complex. They are fearful of not being believed by police, they fear court processes and how they might be treated, they feel ashamed, they are afraid of what their friends and family might think and they may even be persuaded by friends and family to forego reporting (Jordan 2004; Triggs et al. 2009). A New Zealand study estimated that less than $10 \%$ of sexual violence is reported to the police (Weiss 2011). The decision to report is further complicated by their relationship to the perpetrator: at least $75 \%$ are known to the victim (Peterson and Muehlenhard 2010; Weiss 2011). When victims do report to the police, approximately $60 \%$ of those reported do not proceed to trial (Heenan and Murray 2006; Triggs et al. 2009) and even fewer receive convictions (Kelly et al. 2005; Triggs et al. 2009). It should, therefore, be no surprise that calls have been made for '.. judges, criminal lawyers, prosecutors and most importantly [victims] to get around a table ... and come up with something better' (Martin 2006, p. D2).

Accordingly, victim and survivor advocates report they have supported victims as they pursued justice in other ways, such as in face-to-face facilitated meetings and civil cases (Jülich 2006). They do so understanding the importance of justice to the recovery process (Herman 1997, 2005; Jülich 2001). Others have turned to a pathway of justice utilising group conferencing, such as face to face, through advocates, or over telephone, that brings together victim and offender for the purposes of addressing harm and making amends. While supporters would argue that restorative justice could offer a viable alternative to conventional criminal justice systems, the literature is generally not supportive, citing the power imbalance between victim and abuser (McElrea 2004; Parker 2004; van Wormer 2009). Sexual violence typically occurs within a context of abuse of power and is frequently reflective of entrenched societal attitudes and beliefs (van Wormer 2009). Jordan (2004, p. 17) concluded that ' $[w]$ hile gender inequality continues at a social level, women will remain vulnerable to sexual and physical violence in their relationships with men'.

The concept of being treated equally is particularly relevant for victims of sexual violence. Sexual violence as an abuse of power negates the notion of any pre-existent equality between victim and perpetrator. This deeply entrenched power imbalance, existing between men and women within a world that is predominantly defined by men, could preclude any assurance of formal equality, let alone substantive equality in any justice intervention. A lack of equality permeates all societal systems and structures, including conventional criminal justice systems (McGlynn et al. 2012). The same is likely to be true of restorative justice. Indeed, Braithwaite (2002) noted that equality is not possible while some victims agree to restorative processes that might mean a lesser sentence for the offender and other victims do not. Clearly, equality is as much a challenge for restorative justice as it is for conventional justice systems.

The international social work community also recognizes sexual violence as contravening the goal of achieving gender equity and perpetuating the oppression of women and girls. This is demonstrated by the policy position of the International Federation of Social Workers on women, which states in paragraph 2.2 that "Attention must be given to equity in life chances for women and girls over the life course... the continuing worldwide prevalence of various forms of genderbased violence against women and girls remains a major obstacle to the fulfilment of these goals" (International Federation of Social Workers 2016). It is therefore imperative that social workers are aware of the ways in which action or inaction can further or hinder the pursuit of social justice while working with victims of sexual violence; this, in turn, requires acknowledgement of the social nuances in which this work occurs.

Attention to 'human rights' rather than just 'client needs' is increasingly gaining momentum on the social work agenda. Practising from within a human rights framework means that overarching social structures that underpin oppression are considered in the context of individual clients' needs, reducing individual anthologizing and maximizing responsiveness to causes of violence and abuse, not just their symptoms (Lundy 2011; Zaviršek and Herath 2010). The principles ingrained in social work ethics are easily transferable to human rights-based practice, and provide the opportunity for social work as a profession to develop its political awareness to align with the rights of clients (Ife 2008; McPherson 2015). Rightsbased practice attends to disenfranchisement caused through societal inequity, particularly the experiences of the most vulnerable, such as victims of violence - in the context of sociopolitical structures and pursues changes that facilitate the realization of human rights for all (National Association of Social Workers 1999). King (2004) argued that restorative justice provided social workers "opportunities to work within the justice system" and "other institutional settings where social conflict is a focus of their work" (p. 3). There is some overlap of principles and goals between the two fields of practice and the potential of both social work and restorative justice to develop community capacity (Beck 2011). It is not surprising that van Wormer (2004) called for social work to be at the forefront of restorative justice and not lagging behind, but as Beck (2011) noted, the relationship between the two fields of practice has been slow to develop.

For purposes here, the terms sexual violence, sexual assault, sexual abuse and rape are used interchangeably with the understanding that they fall under the umbrella term of 
gendered harm and violence (Triggs et al. 2009). In referring to the survivor of sexual violence, we use the term victim. This is not to suggest that a person subjected to sexual violence as an adult or a child is not a survivor, but use of the term victim highlights the criminal nature of the offending behaviour. For similar reasons, we refer to the perpetrator of this behaviour as the offender, even though in most instances of sexual violence there have been no formal complaints made against the person responsible.

\section{Victims' Perspectives of Justice}

Zehr (1995) argued that an experience of justice, although it had many dimensions, was so basic that, without it, healing could be impossible. Herman (1997) similarly endorsed this stance noting that public acknowledgement and justice were a central pre-occupation for victims, particularly for victims in advanced stages of recovery.

In a research project conducted with a group of adult victims of child sexual abuse throughout the late 1990s, Jülich (2001) investigated how victims perceive justice - the first study of its kind in New Zealand. She reported that as participants reflected on their understandings of justice, it seemed as though justice and recovery were interdependent. They spoke about their need to progress their individual journeys of recovery and how justice was central to this process. Common themes among participants of this study included the desire to gain answers to basic questions from offenders, the desire to confront the offender directly in the presence of their family members, the wish to have their experiences of victimization heard, affirmed, and validated in front of their community and their needs for offenders to demonstrate responsibility and accountability. Rather than giving forgiveness or seeking apologies, their desires for justice were centred on having underlying causes of offending addressed, reducing the risk of others being harmed and the transformation of their relationships with offenders so that they could co-exist in shared communities. Justice for these victims seemed to be about equality and fairness between themselves and the people who offended against them. Achieving a sense of justice as described by Jülich is unlikely in systems where legal constructions of justice emphasize procedural fairness (Fletcher 1996).

Herman's (2005) study produced very similar findings even though participants had more diverse experiences of violence which included not only sexual violence as adults and children but also domestic violence. Participants in this study indicated that acknowledgement, validation and vindication in the context of their families and communities were important components of justice. They too appeared somewhat ambivalent regarding apologies, forgiveness, reconciliation and punishment and spoke of accountability outside of conventional frameworks. Later studies (see McGlynn et al. 2012; van
Wormer 2009) have reinforced these findings. Herman (2005) concluded that restorative justice would fail for the same reasons that conventional systems fail. Both systems are ultimately reflective of the patriarchal structures evident in society: that is the unequal position women hold relative to men. Victims have been sexually victimized because of their unequal position. They have been stigmatized and shamed by the victimization they have been subjected to. Unless restorative justice recognizes entrenched societal structures, it too will fail. For a sense of justice to be experienced, victims not only need to be central to the process but also need to be treated equally. In the next section, we will explore understandings of equality and trace the emergence of feminist arguments and debates.

\section{Equality}

Legally, there are two approaches to equality. The first is to treat all people the same; the second is to accommodate the differences between people. Those that support the equal or same treatment debate, that is formal or procedural equality, claim that emphasizing the difference between men and women infers that women are deviating from the 'norm' (Holtmaat 1989). On the other hand, those that support the different or special treatment debate argue that true equality is based on the recognition of the differing needs of men and women which arise from their different experiences (Barnett 1997). While both the equal or same treatment perspective and the different or special treatment perspective emphasize gender difference, these can be applied also to differences between groups of people, that is the differences between abled and differently abled groups, the differences between middle class, predominantly white groups and those with different racial or ethnic backgrounds, the differences between adults and children or the differences between powerful groups and those who are powerless. This recognition of difference, including the different nature of men and women, is evident in the writing of philosophers such as Aristotle and Kant and is common in the history of philosophy (Mendus 1995).

The Aristotelian approach to equality was to treat like persons alike, and unlike persons unlike (Freeman 1994). It was taken for granted in the days of Aristotle that people in society were not equal, and in his writings, he made it quite clear that in his view people were not equal. More particularly, he believed that women were naturally inferior to men (Barnett 1997). This concept of an assumed inequality was not widely challenged until the Age of Enlightenment or the Age of Reason in the eighteenth century, which began in England during the seventeenth century (Inwood 1995). Immanuel Kant, one of the last writers of this period, argued that '... at the level of ultimate moral value, all human beings [men] are equal' (Fletcher 1996, p. 122). He maintained that unless we 
were committed to a supreme value, human life could then by outweighed by a finite monetary sum, that is a value which could vary between individuals implying that human beings are not equal. One of the common ideas of this time was that '...all men are at all times (and in all places) fundamentally the same in nature' (Inwood 1995, p. 236). The emergence of these ideas in part contributed to the American Revolution of 1776 and the French Revolution of 1789. The American Declaration of Independence states 'all men [i.e. people] are created equal' (Fletcher 1996, p. 121). Yet, at the time this was written, 1776, the writers condoned slavery and the disenfranchisement of women. Clearly, all people were not equal at this time, and neither were all men or all women.

Feminists have debated the concept of equality since Mary Wollstonecraft, when writers questioned discriminatory social practices and policy and challenged conventional beliefs regarding the ability and capacity of women to reason and to benefit from education (Mendus 1995). While these early writers did not claim to be feminists (a term not used in English until the 1890s), they have since been deemed feminist because of the stance they took against the subordination of women (Mendus 1995). Wollstonecraft's book, A Vindication of the Rights of Woman, published in 1792, became the classic formulation of traditional liberal feminism, a perspective that much contemporary feminist theory defines itself against (Tong 1989). Wollstonecraft did not advocate for equality with men in political arenas, but supported a 'differential conception of citizenship' in that women would participate as rational beings from within their homes (Mendus 1995, p. 271).

Almost a hundred years later, John Stuart Mill and Harriet Taylor Mill advocated that for women to achieve sexual equality or gender justice, it was insufficient alone for women to have the same access to education as men: they needed the same civil liberties and economic opportunities (Tong 1989). These authors deviated from Wollstonecraft in that they made no consideration for any natural differences between men and women (Mendus 1995). Likewise, modern liberal feminists have argued that equality for women as rational beings ' ...dictates a single, undifferentiated conception of citizenship which makes no distinction between women and men in respect of their legal and political rights' (Mendus 1995, p. 271).

The concept 'equality of all before the law' continued to be the aim of eighteenth and twentieth century western law (Bianchi 1994), some of which was specifically intended to remove discrimination by making it illegal to discriminate on the grounds of gender, ethnicity or age. This formal, or procedural, equality has attempted to create the same position for women that men have always enjoyed (Holtmaat 1989) - a position that is situated in male structures based on male values and one that demands women accept without criticism. The only women who benefit from the gender-neutral approach to equality are those who have approximated the male norm (MacKinnon 1989). Therefore, by working towards equality for all people, supposedly the greatest achievement of any society, if we are using pre-existing male norms, we are saying that women must aspire to be like men. More importantly, we are sending a message that says 'feminine' values and characteristics are not as important or as valuable to society as 'masculine' values and characteristics.

When the concept of equality is discussed, it begs the question 'equal to what?' Riki Holtmaat (1989) asked why women are to be equal to men. She pointed out that the direction of change is towards the male norm. Catherine MacKinnon (1989, p. 225) queried why women "...have to be the same as a man to get what a man gets simply because he is one". MacKinnon (1989) used this point to argue that Aristotle's understanding of equality, that is to treat like people alike and unlike people unlike, overlooked the fact that the world was defined by men. Some feminists challenged whether equality could "... ever mean anything other than assimilation to a preexisting male norm" (Flax 1993, p. 334).

Daly (1990) claimed that all feminists studying the law acknowledge that formal legal equality does not guarantee substantive equality. Formal legal equality or equality of access not only is based on male standards of equality but also does not recognize the established structural inequalities that exist within society (Waring 1996). By contrast, substantive equality, or equality of outcome, recognizes the general social and economic position of women as a cause of their suppression, and the importance of biological and social differences between men and women. It is these differences that negate women's abilities and capacities to make the same use of formal rights as men (Mendus 1995). Central to substantive equality or equality of outcome is the understanding that while overt structures fostering inequality and discrimination may be removed through law, the covert structures remain firmly in place. Notably, Scales (1980/81, p. 1396) commented that "[i] njustice does not flow directly from recognizing differences; injustice results when those differences are transformed into social and economic deprivation".

The challenge is to ensure equality over difference. Some feminists have focused on the goal of special rights or have advocated for the development of new frameworks within which substantive equality may be achieved (Daly 1990). Holtmaat (1989) argued that special rights for women maintain the status quo as essentially male. She pointed out that two categories of rights would exist, normal rights for men and women without differentiation, and special rights for women only. Neither of these two categories accommodates differentiation. Until such time that a framework is established which accommodates difference, there will be no substantive equality. Neither will we realize Kant's understanding of equality, that is the notion of an ultimate moral value for all human life which includes men, women, children, people of colour and people living with disabilities. 
Human rights instruments exist that uphold the notion of substantive equality. Given that sexual violence is recognized internationally as a breach of human rights (Herman 1997), we will briefly review these instruments in the following section.

\section{Human Rights Documents}

Gender-neutral treatment, or formal equality, was adopted and reflected in early 'male-centred human rights documents' (Waring 1996, p. 108). For example, the United Nations Universal Declaration of Human Rights (1948) stated "[a] 11 human beings are born free and equal in dignity and right" (Freeman 1994, p. 193). Article 1 goes on to state that "...we should act towards one another in a spirit of brotherhood". The essence of Article 1 is clearly understood, yet over "...half the people on the planet..." are women and unable to experience brotherhood (Waring 1996, p. 123). If not for the insistence of Eleanor Roosevelt and other women present at that time, 'sex' would not have been included in Article 2 as an area of discrimination (Waring 1996). It is interesting to note that while Eleanor Roosevelt advocated for gender-neutral language such as 'all human beings' instead of 'all men', it appears that neither she or others challenged the word 'brotherhood' (Glendon 2001, p. 112). However, she did make it clear that that 'equality did not mean identical treatment for men and women' and that there were circumstances 'where differential treatment was essential' (Glendon 2001, p. 112). The international community was frustrated by the vague nature of the declaration and so the objectives were translated into two covenants which were adopted in 1966 (MacNaughton 2009): the United Nations International Covenant on Civil and Political Rights (ICCPR) and the International Covenant on Economic, Social and Cultural Rights (ICESCR).

The two covenants, together with the Universal Declaration of Human Rights, recognize that "... the inherent dignity and the equal and inalienable rights of all members of the human family is the foundation of freedom, justice and peace in the world ..." (United Nations 1948; Waring 1996, pp. 164,170). The ICCPR embodies an extensive list of rights including, among others, the right to equality and non-discrimination, the right to effective judicial and other remedies, the protection of the family and the right of the child to special measures of protection (MacNaughton 2009). The ICESCR encompasses employment rights, social security rights, protection and assistance to the family, standards of living, health, education and the right to participate in scientific and cultural life (OHCHR 1976).

Following the adoption of these two general instruments, the United Nations adopted a number of specialized treaties. Among these are CEDAW and the United Nations
Conventions on the Rights of the Child (UNCROC). Adopted in 1979, CEDAW prohibits all forms of discrimination against women. It recognizes that the enactment of gender-neutral law is insufficient to ensure this basic legal norm; that is formal equality does not ensure substantive equality. Furthermore, the covenant states that "... the full and complete development of a country, the welfare of the world and the cause of peace require the maximum participation of women on equal terms with men in all fields" (OHCHR 1979). Similarly, UNCROC, adopted a decade after CEDAW, condemns the perpetration of all types of abuse in Article 19, including sexual abuse against persons under 18, and requires signatories to act to prevent and address abuse of children and young people (OHCHR 1989). Despite being one of the most widely ratified conventions, with more than 185 member parties, CEDAW is one of the most heavily reserved conventions (Mahoney 2005) with most reservations being against core articles (Shin 2004). It is ironic that the United Nations convention working to eliminate discrimination against women is itself discriminated against when compared to other international treaties.

A further instrument, the Declaration of Basic Principles of Justice for Victims of Crime and Abuse of Power, was adopted in 1985. This declaration states that victims should have access to justice and fair treatment (OHCHR 1985). It should be noted that experts have recently convened to draft a Convention on Victims of Crime, Abuse of Power and Terrorism for eventual adoption by the United Nations General Assembly (Human Rights Commission 2011); although it will be some time before the current declaration is converted to a United Nations covenant, it is a strong message from the international community regarding the status of victims in criminal proceedings.

While the United Nations has no formal means of enforcing treaties other than international peer pressure, it is embarrassing for a nation to be found wanting in terms of compliance to a treaty it has ratified. Committees monitor the degree of compliance to the various instruments through regular reports provided by member countries, nongovernmental organizations and other international bodies. As with all United Nations instruments, those countries that ratify treaties have an obligation to reflect the treaty's principles in domestic legislation and policy. Although these countries might have legislation in place that guarantees formal equality, statistics relating to reporting rates of sexual violence indicate that this has been less than successful. It should be noted that both ICCPR and CEDAW have optional protocols that enable individuals to take claims to the United Nations Human Rights Commission once they have exhausted all domestic remedies (Waring 1996).

The United Nations human rights covenants and conventions, in particular CEDAW, embody Kant's understanding of equality and, despite the difficulties they face, provide the 
basis for substantive equality. To date, these intentions have not transferred to Western legal systems. Conventional criminal justice systems have only guaranteed equality of access; they have not embodied the principles of substantive equality. A justice system that could embody these principles might be more able to provide victims of sexual violence with an experience of justice. To ensure that all people have opportunity of outcome, it might mean that some people are treated differently. Conventional criminal justice systems to date have been unable to achieve this, but it may well be different for restorative justice. In the next section, we will briefly review the development of restorative justice and its practice before identifying any implications for practice.

\section{The Development of Restorative Justice}

When describing the rise of restorative justice in the 1970s, writers have tended to describe it as a re-emergence of old values and practices, noting its historical roots and indigenous influences. They have commented on the influence of various strands of activism and social movements prominent at the time, including, among others, the human rights movement, the indigenous renaissance, abolitionism, the rise of the victim movement, feminism and the adoption of neo-liberalism as a political ideology in Great Britain, the USA and New Zealand (Daly and Immarigeon 1998; Liu 2007; Pavlich 2005). It almost seems as though these various strands have coalesced to support the development of restorative justice. Importantly, these accounts, although they might not have claimed such, have tended to give the impression that victims or their advocates were influential in the development of restorative justice practice.

Despite claims that restorative justice is victim-centred, victims and their advocates were not actively engaged in early practice development (Mika et al. 2004). Early practitioners were largely defendant-oriented (Herman 2005), churchbased (Fromme 2007; Pavlich 2005) and driven by “... religious or progressive concerns for the fate of criminal defendants ..." (Herman 2005, p. 578) amid increasing crime rates and an increasingly punitive environment of harsher sentencing. Herman $(2005$, p. 579$)$ argued that the absence of a strong victim voice has "... reproduced many of the same deficiencies as the traditional justice system in respect to victims' rights". In the early days, victims were not central to restorative justice. The profound nature of this absence was highlighted by Zehr's comments at a New Zealand hui (Māori term for meeting) in 2002: " $[\mathrm{I}] \mathrm{t}$ took me a long time to realize how deeply embedded the offender orientation is in so many of us, and in our concept of justice..." (Jülich 2003, p. 45). The same critique could be made of the theory that emerged to support the practice of restorative justice. As Ashworth (2002) noted, theory development has tended to be led by practice. Victims' voices were similarly absent.

Early theorists tended to talk about restorative justice as a different or new lens through which to view justice (Zehr 1995), or as a third way to do justice (Bazemore 1998). This invoked a perception of restorative justice as an alternative to the more conventional models of criminal justice based on rehabilitation or retribution. While there are a number of restorative justice programs working alongside conventional criminal justice systems, or offering justice resolutions to those parties who opt for more informal processes outside of conventional systems, restorative justice as yet has not displaced conventional criminal justice. At best, it has become an adjunct or an additional layer that victims and offenders can choose to negotiate (Behrens 2005; McGlynn et al. 2012; Mika et al. 2004). Restorative justice is working within the flawed structures of conventional criminal justice systems and, potentially, replicating the deficiencies it aims to negate, such as patriarchy and imbalances of power (Strang 2002). The same is true of those restorative justice programs operating outside of the criminal justice system.

There may have been a lack of victim presence in the early development of restorative justice, both practice and theory, but victim advocates and feminists did recognize that conventional criminal justice systems were not only failing victims but also, in many instances, re-victimizing them. Their activism pursued different objectives, and so it is only more recently that victim advocates have begun to make alliances with restorative justice. However, many advocates have remained sceptical of the motivations of restorative justice and its claims on behalf of victims (Strang 2002; van Wormer 2009). Perhaps the most constant critique of restorative justice has been that of feminist writers. They have argued that restorative justice has not addressed structural inequality, discrimination or oppression, neither has it resolved pre-existing power imbalances between victim and offender, in particular for those offenders and victims who have a prior relationship or are known to each other (Stubbs 2002), as they most often are in sexual violence. Also, it would seem that some restorative processes might have further re-victimized victims by misusing power and coercion or they have used victimoffender encounters for the benefit of offenders (Braithwaite 2002; Strang 2002). There is some concern, for example, that a reduction in the severity of penalties following participation in a restorative process may encourage offenders to assume responsibility solely to access lighter sentences; however, this is offset by the requirement that offenders assume responsibility - and therefore enter guilty pleas - in order to participate (Ministry of Justice 2013), which, given the minimal rates of accountability within the criminal justice system for sexual violence, is favourable to victims. Yet, despite these shortcomings, evaluations of restorative justice consistently have found that victims are satisfied with the process (Latimer et al. 2005). 
Although such evaluations are compromised by the very nature of restorative justice - the self-selection bias, that is its voluntary nature and the willingness of parties to participate (Latimer et al. 2005) - the fact remains that restorative justice has a certain appeal.

\section{Implications for Restorative Justice}

Restorative justice has the same responsibility to uphold human rights as does the conventional criminal justice system. Despite their imperfections, the United Nations instruments are well established, having been debated, reflected on over the last few decades and, further, accepted internationally (Braithwaite 2002). It is difficult to argue with Braithwaite's (2002, p. 13) suggestion that the United Nations covenants would provide '.. guidance on the values restorative justice processes ought to observe'. These values must include substantive equality. To not include them is to perpetuate inequality by, as some would argue, supporting and sustaining violence (McDermott 1994, p. 27).

While there would be little argument among restorative justice advocates regarding the protection of fundamental human rights (Walgrave 2002), there would be debate as to whose rights should take precedence: the victim or the offender. Treating offenders and victims differently within restorative justice processes might seem as though the rights of one are not being upheld. On consideration, Braithwaite (2002, p. 126) concluded that '...equality for victims and equality for offenders are utterly irreconcilable... ' However, these comments are made in the context of legal rights pertaining to the conventional criminal justice system, not as they might pertain to restorative justice. Walgrave (2002) argued that legal rights do not transfer easily from the conventional criminal justice model to a restorative model. Accordingly, he proposed that legal theory on restorative justice be reconstructed accommodating the different world view on which restorative justice is premised.

\section{Specific Considerations for Sexual Violence Cases}

Restorative justice and its utility for sexual crimes are entangled with the role of the facilitator and the requirement for non-neutrality. The concepts of 'neutrality' and 'impartiality' are distinguished by the notion of fairness, as neutrality indicates a removal of values from process, while impartiality ensures fairness through equal treatment or the commitment to equitable participation. Neutrality can therefore be understood as the removal of personal investment or bias regarding outcomes, while impartiality manifests through fair process (Kishore 2006). Justice principles are considered neutral if they are not premised on subjective judgments of what constitutes a 'conception of the good', that is which values give positive meaning to life (Caney 1996). When convening a process involving two or more parties, true neutrality is considered unrealistic and unattainable, as it requires facilitators to be indifferent to participant welfare, not intervene, ignore power imbalances, have no outcome expectations and possess no interest in the impact on any party. Conversely, while impartiality requires unbiased participation, it also inherently requires attention to any power differential, intervention in the face of coercion and a commitment to maintaining informed consent (Kishore 2006), all of which become even more vital when considering the imbalanced nature of power dynamics experienced in incidents of sexual violence.

Sexual crimes present unique challenges to the delivery of effective justice processes. Offenders typically deny the offending, and sexual crimes are notoriously difficult to secure convictions. Participation in restorative processes therefore enables earlier admissions of guilt and, by extension, giving victims the satisfaction of having their victimization acknowledged (McGlynn et al. 2012). Moreover, actors within the justice system are susceptible to the same flawed beliefs about sexual violence prevalent across society; correspondingly, typically only offences reflecting 'traditional' notions of sexual violence (i.e. stranger rape involving significant violence) are progressed to a trial (Koss 2015). Finally, offenders usually claim innocence on the advice of legal counsel, denying victims' acknowledgement and validation of harm, while victims are compelled to withstand re-traumatizing and emotionally challenging court procedures with minimal likelihood of achieving a guilty verdict for their offenders (Koss 2015). Victim participation in formal systems following an offence is therefore disproportionately harmful in sexual offences than other categories of crime, indicating the need for actors within alternative systems of justice to receive specialist training. McGlynn et al. (2012) conclude there must be 'extensive debate and consultation among different professional communities engaged in this line of work, including restorative justice practitioners, those working with offenders, and those organizations such as rape crisis which work with victim-survivors of violence' (p. 236-7).

Stubbs (1997) raised the concern that power imbalances and coercive tactics intrinsic to gendered harm would be replicated throughout restorative practices, potentially harming victims further. Whether this assertion is realized is largely dependent on the extent to which the need for specialist providers is acknowledged and provided for by regional funding bodies, as it is generally agreed by experts in the field that a generic restorative process is unsuitable for sexual crimes (Busch 2002; McGlynn et al. 2012). This is echoed by the United Nations guidelines for restorative processes following gendered harm, which instruct professional participants to attend to both implicit and explicit exercising of coercive power and manipulation at all stages of the process, necessitating 
specialist, tailored training for all professionals involved in the process (UN Office on Drugs and Crime 2006).

The challenge for restorative justice is to ensure practice incorporates the principles of substantive equality — not just between offenders but also between the victim and the offender. There is a lack of research regarding how to achieve equal treatment between victims and offenders (Marshall and Merry 1990, cited in Strang 2002). While these comments were made in relation to restorative justice, it should be noted that there is no similar research relevant to conventional criminal justice systems. In fact, conventional criminal justice systems neither provide equal treatment nor claim to provide equal treatment between victims and offenders. Victims are more likely to experience substantive equality in a model which has the potential to address the critiques which have been made of restorative justice (Jülich 2001; Strang 2002).

\section{Hopes and Concerns Among Victim Advocates}

There is currently a dearth of research on the utility of restorative justice for sexual violence (particularly evaluation studies); consequently, 'the debate' is predominately based on ideological concerns regarding the appropriateness of restorative processes for gendered crimes (Daly and Curtis-Fawley 2006; Proietti-Scifoni and Daly 2011; Strang and Braithwaite 2002). Opponents of the use of restorative justice in sexual crimes often express concern that restorative processes divert cases from the formal system, thereby precluding any opportunity for 'suitable' punishment. However, as discussed above, restorative justice can occur in conjunction with or at various stages of offenders' participation in the criminal justice system. An additional concern is that offenders escape punishment by opting instead for 'reparation'; however, it is important to note that these two avenues are not mutually exclusive: acts of reparation may sit alongside and complement more traditional methods of punishment (McGlynn et al. 2012).

Researchers have unanimously found that traditional models of justice fail female victims; of a National Violence Against Women survey identifying 2594 experiences of rape, only 9 resulted in conviction and subsequent imprisonment (Koss 2015). Proietti-Scifoni and Daly's (2011) research evidenced the wide range of benefits and concerns expressed by New Zealand advocates - both of which, paradoxically, are predicated on the nature of the power relationship between victim and offender. Perceived benefits included increased victim participation and input, improved scope for validation and acknowledgement, a greater likelihood that offenders would be held accountable, opportunities to challenge offenders' minimization or denial of harm caused and the potential to address harmful dynamics of the victim-offender relationship if the victim wishes. Conversely, concerns include the potential for negative impacts on women, such as by negating physical safety, enabling continued manipulation, repetition of pre-existing power imbalances and allowing other participants to collude with the offender; the possibility that one meeting may not be sufficient to effect change; the degree to which consent is fully informed; and the perception of restorative processes as being tantamount to leniency (ProiettiScifoni and Daly 2011). Advocates' levels of concern increased substantially when confronted with the prospect of having children present for restorative processes following child sexual abuse, although the majority expressed support for the scenario provided the child was not present for the conference (Proietti-Scifoni and Daly 2011). However, victim advocates (Daly and Curtis-Fawley 2006; Jülich 2010; Koss 2006) also overwhelmingly support the need for alternative avenues for justice to be explored as a result of the criminal justice system's failure to provide a sense of justice to victims. Those who supported restorative justice processes did so on the condition that these processes were voluntary, that victims and offenders were well-informed and sufficiently prepared and that facilitators were well-trained with specialist knowledge of the dynamics of sexual violence (Proietti-Scifoni and Daly 2011).

Advocates of a standpoint feminist perspective, which is grounded in the elevation of women's voices, condemn the effects of conventional management of women's complaints of sexual violence, but do not unreservedly endorse restorative processes as an automatically preferable substitute (van Wormer 2009). Despite these reservations, feminist researchers do acknowledge that restorative processes can provide the opportunity for dialogue, thereby enabling women to speak for themselves (Gilligan 1982), constituting the 'giving of voice' heralded as essential in managing situations of gendered power imbalances as identified by Bui (2007). Shifting the primary goal from 'revenge' to 'resolution' and providing space for the special meanings women attribute to their experience to be heard and integrated into the process (Failinger 2006) aligns restorative processes closely with the feminist goals of respecting varied realities in relation to oppression, promoting dignity and worth of marginalized people and addressing power differentials at individual and structural levels (van Wormer 2009). Two particularly powerful notions highlight the congruence between restorative justice and feminism; namely truth-telling and choice. Truth-telling in this instance refers to the opportunity for victims to '[tell] their stories in their own words and styles' (van Wormer 2009), while choice is exemplified in the voluntary and survivor-guided nature of restorative processes - the survivor participates inasmuch as (s)he chooses and has the power to withdraw. This is contrary to participation in the criminal justice system, where selfdetermination is further eroded and attendance may be compulsory and intimidating, particularly for women who distrust authorities or have already been subject to systemic marginalization (van Wormer and Roberts 2009). 
Equality, and the seeking of mechanisms to facilitate it, is a core aim of social work practice. At present, social workers employed in the sexual violence field typically have little involvement with the justice process occurring alongside therapeutic processes for their clients. As previously noted, restorative justice provides opportunities to work within justice systems. In this article, the paramountcy of identifying avenues that enhance equality, including those designed to deliver justice, is made evident. Social workers practising in this field should consider the potential appropriateness of restorative justice as a pathway for clients wishing to regain voice and power after sexual victimization, and the relative risks and benefits of engaging in restorative justice given the available evidence about the use of it as an instrument for advancing equality.

\section{Conclusion}

Sexual violence has a far-reaching effect on victims. Sexual crimes are drastically under-reported. In instances where they are reported, progression through the conventional criminal justice system is notoriously problematic, and the outcomes are dissatisfying. While there has been significant interest in alternative methods of justice out of necessity, the appropriateness of restorative justice as a desirable model for sexual violence is much debated, due to the potential for continued power imbalances between victim and offender and the fear that participation could reinforce such inequalities. The recognition of entrenched societal structures and concurrent efforts to ameliorate these during participation is therefore integral to the notion of equality within restorative processes, which necessitates the prioritization of substantive equality above procedural equality.

CEDAW and the covenants from which this Convention arose, and to a lesser extent the Declaration of Basic Principles of Justice for Victims of Crime and Abuse of Power, clearly embody the intention of substantive equality; however, this intention has not been imputed onto justice systems internationally. The use of restorative justice, which has the potential to actively address elements of inequality such as coercion throughout the process, is arguably more closely aligned with the intention espoused within these human rights documents. The extent to which these issues are actively addressed in restorative processes is consequently the subject of much controversial debate, with restorative justice being positioned both as an 'easy out' for the offender and a risk to the victim and as a genuinely hopeful avenue for justice that may be less re-traumatizing and give greater voice to survivors. This, however, requires very specific procedures to safeguard consent, and specialist providers who are equipped to recognize and address coercive tactics and other indicators of a power differential occurring within the process.

\section{References}

Ashworth, A. (2002). Responsibilities, rights and restorative justice. British Journal of Criminology, 42(3), 578-595. doi:10.1093/bjc/ 42.3.578.

Barnett, H. (1997). Sourcebook on feminist jurisprudence. London: Cavendish Publishing Ltd..

Bazemore, G. (1998). Restorative justice and earned redemption: communities, victims and offender reintegration. The American Behavioral Scientist, 41(6), 676-813. doi:10.1177/0002764298041006003.

Beck, E. (2011). Introduction. In E. Beck, N. P. Kropf, \& P. B. Leonard (Eds.), Social work and restorative justice: skills for dialogue, peacemaking, and reconciliation (pp. 3-14). New York: Oxford University Press.

Behrens, J. (2005). Meeting the needs of victims of domestic violence with family law issues: the dangers and possibilities of restorative justice. International Journal of Law in Context, 1(3), 215-235. doi: 10.1017/S1744552305003010.

Bianchi, H. (1994). Justice as sanctuary. Bloomington and Indianapolis: Indiana University Press.

Braithwaite, J. (2002). Restorative justice and responsive regulation. New York: Oxford University Press.

Bui, H. (2007). The limitations of current approaches to domestic violence. In S. Miller (Ed.), Crime control and women (pp. 151-180). Thousand Oaks: Sage Publications.

Busch, R. (2002). Domestic violence and restorative justice initiatives: who pays if we get it wrong? In H. Strang \& J. Braithwaite (Eds.), Restorative justice and family violence (pp. 223-248). Cambridge: Cambridge University Press.

Caney, S. (1996). Impartiality and liberal neutrality. Utilitas, 8(3), $273-$ 293. doi:10.1017/S0953820800005008.

Daly, K. (1990). Reflections on feminist legal thought. Social Justice, 17(3), 7-24.

Daly, K., \& Curtis-Fawley, S. (2006). Restorative justice for victims of sexual assault. In K. Heimer \& C. Kruttschnitt (Eds.), Gender and crime: patterns of victimisation and offending (pp. 230-265). New York: New York University Press.

Daly, K., \& Immarigeon, R. (1998). The past, present, and future of restorative justice: some critical reflections. Contemporary Justice Review, 1(1), 21-45.

Failinger, M. A. (2006). Lessons unlearned: women offenders, the ethics of care, and the promise of restorative justice. Fordham Urban Law Journal, 33(2), 487-527.

Flax, J. (1993). The play of justice: justice as transitional space. Political Psychology, 14(2), 331-346. doi:10.2307/3791414.

Fletcher, G. P. (1996). Basic concepts of legal thought. New York: Oxford University Press.

Freeman, M. D. A. (1994). Lloyd's introduction to jurisprudence (6th ed.). London: Sweet and Maxwell.

Fromme, J. (2007). Restorative justice and human rights. British Columbia: (Master of Arts), Royal Roads University.

Gilligan, C. (1982). In a different voice: psychological theory and women's development. Cambridge, MA: Harvard University Press.

Glendon, M. A. (2001). A world made new: Eleanore Roosevelt and the Universal Declaration of Human Rights. New York: Random House.

Heenan, M., \& Murray, S. (2006). Study of reported rapes in Victoria 2000-2003: summary research report. Melbourne: Office of Women's Policy, Department for Victorian Communities.

Herman, J. L. (1997). Trauma and recovery: the aftermath of violencefrom domestic abuse to political terror. London: Basic Books.

Herman, J. L. (2005). Justice from the victim's perspective. Violence Against Women, 11(5), 571-602. doi:10.1177/1077801205274450. 
Holtmaat, R. (1989). The power of legal concepts: the development of a feminist theory of law. International Journal of the Sociology of Law, 17, 481-502.

Human Rights Commission. (2011). Submission on the Victims of Crime Reform Bill. Retrieved January 192017 from https://www. parliament.nz/resource/0000181019.

Ife, J. (2008). Human rights and social work: towards rights-based practice. Cambridge: Cambridge University Press.

International Federation of Social Workers. (2016). Women. Retrieved January 222017 from http://ifsw.org/policies/women/

Inwood, M. J. (1995). Enlightenment. In T. Honderich (Ed.), The Oxford companion to philosophy (pp. 236-237). Oxford: Oxford Press.

Jordan, J. (2004). The word of a woman: police, rape and belief. New York: Palgrave, MacMillan.

Jülich, S. (2001). Breaking the silence: restorative justice and child sexual abuse. (PhD Thesis), Massey University, Albany. Retrieved from http://mro.massey.ac.nz/handle/10179/2110

Jülich, S. (2006). Views of justice among survivors of historical child sexual abuse: Implications for restorative justice in New Zealand. Theoretical Criminology, 10(1), 125-138. doi:10.1177/ 1362480606059988.

Jülich, S. (2010). Restorative justice and gendered violence in New Zealand: a glimmer of hope. In J. Ptacek (Ed.), Restorative justice and violence against women (pp. 239-254). New York: Oxford University Press.

Jülich, S. (Ed.). (2003). Critical issues in restorative justice: advancing the agenda in Aotearoa, New Zealand. Auckland: Centre for Peace and Justice Development, Massey University.

Kelly, L., Lovett, J., \& Regan, L. (2005). A gap or a chasm? Attrition in reported rape cases. London: Home Office Research.

King, S. (2004). Social work and restorative justice. Paper presented at the Global Social Work Conference, Adelaide, Australia. Retrieved April 62017 from https:/www.unisa.edu.au/Documents/EASS/ HRI/SPRG/social-work-and-restorative-justice.pdf

Kishore, S. (2006). The evolving concepts of neutrality and impartiality in mediation. Commonwealth Law Bulletin, 32(2), 221-225. doi:10. 1080/03050710600907056.

Koss, M. P. (2006). Restoring rape survivors. Annals of the New York Academy of Sciences, 1087(1), 206-234. doi:10.1196/annals.1385. 025 .

Koss, M. P. (2015). Restorative justice for sex crimes outside the context of intimate partner violence. Family and Intimate Partner Violence Quarterly, 7(4), 307-316.

Latimer, J., Dowden, C., \& Muise, D. (2005). The effectiveness of restorative justice practices: a meta-analysis. The Prison Journal, 85(2), 127-144. doi:10.1177/0032885505276969.

Liu, J. H. (2007). Social and historical contexts for restorative and retributive justice: Te Ao Po-Te Ao Marama (worlds of light and dark). In G. Maxwell \& J. H. Liu (Eds.), Restorative practices in New Zealand: towards a restorative society. Wellington: Institute of Policy Studies, Victoria University.

Lundy, C. (2011). Social work, social justice, and human rights: a structural approach to practice ( 2 nd ed.). Toronto: University of Toronto Press.

MacKinnon, C. A. (1989). Toward a feminist theory of the state. Cambridge: Harvard University Press.

MacNaughton, G. (2009). Untangling equality and nondiscrimination to promote the right to health care for all. Health and Human Rights, 11(2), 47-63.

Mahoney, K. (2005). Response to Hans Kung's remarks on global ethic and human responsibilities. Retrieved January 212017 from http:// nautilus.org/gps/applied-gps/global-ethics/a-global-ethic/

Marshall, T. F., \& Merry, S. (1990). Crime and Accountability: Victim offender mediation in practice. London: HMSO

Martin, Y. (2006, May 27). The rape crisis, The Press, pp. D1-D2.
Mayhew, P., \& Reilly, J. (2007). New Zealand crime \& safety survey : 2006. Retrieved from http://ndhadeliver.natlib.govt.nz/delivery/ DeliveryManagerServlet?dps pid=IE763503

McDermott, M. J. (1994). Criminology as peacemaking, feminist ethics and the victimization of women. Women and Criminal Justice, 5(2), 21-44. doi:10.1300/J012v05n02 03.

McElrea, F. W. M. (2004). Restorative justice: New Zealand perspectives - strengths and weaknesses. Auckland: Paper presented at the Third Biennial Conference of the Australian and New Zealand Association for the Treatment of Sexual Abusers Conference.

McGlynn, C., Westmarland, N., \& Godden, N. (2012). 'I just wanted him to hear me': sexual violence and the possibilities of restorative justice. Journal of Law and Society, 39(2), 213-240. doi:10.1111/j. 1467-6478.2012.00579.x.

McPherson, J. (2015). Human rights practice in social work: a US social worker looks to Brazil for leadership. European Journal of Social Work, 18(4), 599-612. doi:10.1080/13691457.2014.947245.

Mendus, S. (1995). Feminism. In T. Honderich (Ed.), The Oxford companion to philosophy (pp. 270-272). Oxford: Oxford University Press.

Mika, H., Achilles, M., Halbert, E., Amstutz, L. S., \& Zehr, H. (2004). Listening to victims: A critique of restorative justice policy and practice in the United States. Federal Probation, 68(1), 32-38.

Ministry of Justice. (2013). Restorative justice standards for sexual offending cases. Retrieved April 82017 from https://www.justice. govt.nz/assets/Documents/Publications/Restorative-justicestandards-for-sexual-offending-cases.pdf

National Association of Social Workers. (1999). Code of ethics of the National Association of Social Workers. Washington, DC: National Association of Social Workers.

OHCHR. (1976). International covenant on economic, social and cultural rights. Retrieved April 32017 from http:/www.ohchr.org/EN/ ProfessionalInterest/Pages/CESCR.aspx

OHCHR. (1979). Convention on the elimination of all forms of discrimination against women Retrieved April 32017 from http://www. ohchr.org/EN/ProfessionalInterest/Pages/CEDAW.aspx

OHCHR. (1985). Declaration of basic principles of justice for victims of crime and abuse of power. Retrieved January 222017 from http:// www.ohchr.org/EN/Professionalinterest/Pages/ VictimsOfCrimeAndAbuseOfPower.aspx.

OHCHR. (1989). Convention on the rights of the child. Retrieved January 212017 from http://www.ohchr.org/en/ professionalinterest/pages/crc.aspx

OHCHR. (2014). Status of ratification: interactive dashboard. Retrieved April 62017 from http://indicators.ohchr.org/

Parker, W. (2004). Restorative justice and family violence: an overview of the literature. Wellington: Ministry of Justice.

Pavlich, G. (2005). Governing paradoxes of restorative justice. London: Glasshouse Press.

Peterson, Z. D., \& Muehlenhard, C. L. (Eds.). (2010). Conceptualizing the "wantedness" of women's consensual and nonconsensual sexual experiences: implications for how women label their experiences with rape (3rd ed.). New York: Oxford University Press.

Proietti-Scifoni, G., \& Daly, K. (2011). Gendered violence and restorative justice: the views of New Zealand Opinion Leaders. Contemporary Justice Review, 14(3), 269-290. doi:10.1080/10282580.2011. 589666.

Scales, A. C. (1980/81). Towards a feminist jurisprudence. Indiana Law Journal, 56(3), 375-444.

Shin, H. (2004). CEDAW and women's human rights: achievements and obstacles. Retrieved January 222017 from https://www.monash. edu/ data/assets/pdf file/0010/138664/heisoo-shin-paper.pdf

Strang, H. (2002). Repair or revenge: victims and restorative justice. New York: Oxford University Press.

Strang, H., \& Braithwaite, J. (Eds.). (2002). Restorative justice and family violence. Cambridge: Cambridge University Press. 
Stubbs, J. (1997). Shame, defiance and violence against women: a critical analysis of "communitarian" conferencing. In J. Bessant \& S. Cook (Eds.), Women's encounters with violence: Australian experiences (pp. 109-126). Thousand Oaks: Sage.

Stubbs, J. (2002). Domestic violence and women's safety: feminist challenges to restorative justice. In H. Strang \& J. Braithwaite (Eds.), Restorative justice and family violence (pp. 42-61). Cambridge: Cambridge University Press.

Tong, R. (1989). Feminist thought: a comprehensive introduction. London: Routledge.

Triggs, S., Mossman, E., Jordan, J., Kingi, V. (2009) Responding to sexual violence: attrition in the criminal justice system. Ministry of Women's Affairs: Wellington, New Zealand. Retrieved from http:// women.govt.nz/sites/public_files/responding $\% 20$ to $\% 20$ sexual $\%$ 20violence\%20attrition-pdf.pdf

UN Office on Drugs and Crime. (2006). Handbook on restorative justice programmes. Retrieved January 202017 from www.unodc.org/pdf/ criminal_justice/06-56290_Ebook.pdf

UN Women. (2009). Convention of the elimination of all forms of discrimination against women: general recommendations made by the Committee on the Elimination of Discrimination against Women. Retrieved January 202017 from http://www.un.org/womenwatch/ daw/cedaw/recommendations/recomm.htm

United Nations. (1948). The universal declaration of human rights. Retrieved January 222017 from http://www.un.org/en/universaldeclaration-human-rights/index.html van Wormer, K. (2004). Confronting oppression, restoring justice: from policy analysis to social action. Alexandria: Council of Social Work Education.

van Wormer, K. (2009). Restorative justice as social justice for victims of gendered violence: a standpoint feminist perspective. Social Work, 54(2), 107-116. doi:10.1093/sw/54.2.107.

van Wormer, K., \& Roberts, A. (2009). Death by domestic violence: preventing the murders and murder-suicides. Westport CT: Praeger.

Walby, S., \& Myhill, A. (2001). New survey methodologies in researching violence against women. British Journal of Criminology, 41, 505-522.

Walgrave, L. (2002). Restorative justice and the law: socio-ethical and juridical foundations for a systemic approach. In L. Walgrave (Ed.), Restorative justice and the law (pp. 191-218). Devon: Willan Publishing.

Waring, M. (1996). Three masquerades. Auckland: Auckland University Press.

Weiss, K. G. (2011). Neutralizing sexual victimization: a typology of victims' non-reporting accounts. Theoretical Criminology, 15(4), 445-467. doi:10.1177/1362480610391527.

Zaviršek, D., \& Herath, S. M. K. (2010). 'I want to have my future, I have a dialogue': social work in Sri Lanka between neo-capitalism and human rights. Social Work Education, 29(8), 831-842. doi:10.1080/ 02615479.2010 .516987$.

Zehr, H. (1995). Changing lenses: a new focus for crime and justice. Scottdale: Herald Press. 